\title{
ANALISIS KETERAMPILAN TEKNIK DASAR BOLA BASKET PADA SISWA SMAN 1 TENGGARONG SEBERANG
}

\author{
Aditya Abdi Nugraha, Hamdiana S.Pd, M.Pd., Jance J Sapulete S.Pd, M.Pd \\ Pendidikan Jasmani Kesehatan dan Rekreasi \\ Adityaabdi33@gmail.com
}

\begin{abstract}
ABSTRAK
Penelitian ini bersifat deskriptif yang mencoba mendeskripsikan keterampilan teknik dasar permainan bola basket pada siswa SMAN 1 Tenggarong Seberang. Populasi dalam penelitian ini adalah siswa kelas XII ipa 2 dan XII ipa 3 SMAN 1 Tenggarong Seberang yang berjumlah 20 orang, sedangkan pengambilan sampel menggunakan teknik sampling kebetulan atau sampling seadanya. Teknik Pengumpulan data dengan menggunakan tes keterampilan teknik dasar bola basket yang terdiri atas melempar dan menangkap (pssing), memasukan bola ke keranjang (shooting) dan menggiring bola (dribbling). Teknik analisis data menggunakan analisis deskriptif, uji normalitas, dan pengkategorian hasil.

Berdasarkan hasil keseluruhan tes keterampilan teknik dasar bola basket pada siswa SMAN 1 Tenggarong Seberang, dari 12 siswa menunjukkan bahwa sebanyak 4 siswa yang memperoleh kategori "baik", 5 siswa yang memperoleh kategori "cukup", 2 siswa yang memperoleh kategori "kurang", dan 1 siswa yang memperoleh kategori sangat "kurang". Maka dapat disimpulkan dari nilai rata-rata yaitu 149,99, bahwa tingkat keterampilan teknik dasar permainan bola basket siswa yang berminat dalam olahraga bola basket di SMAN 1 Tenggarong Seberang masuk dalam kategori "Cukup". Dan untuk 8 siswi menunjukan sebanyak 1 siswi yang memperoleh kategori "sangat baik", 5 siswi yang memperoleh kategori “cukup", dan 2 siswi yang memperoleh kategori "kurang". Maka dapat disimpulkan dari nilai rata-rata yaitu 149,84, bahwa tingkat keterampilan teknik dasar permainan bola basket siswi yang berminat dalam olahraga bola basket di SMAN 1 Tenggarong Seberang masuk dalam kategori "Cukup". Hasil tersebut menunjukkan keterampilan yang dimiliki siswa dan siswi berbeda-beda dan masih banyak siswa dan siswi yang kurang terlatih dalam penguasaan teknik-teknik dasar olahraga bola basket.
\end{abstract}

Kata Kunci: Basket, Bola Basket, Passing , Dribble, Shooting 


\section{Pendahuluan}

A. Latar Belakang Penelitian

Berdasarkan pengalaman saya pada saat melaksanakan PPL di SMAN 1 Tenggarong Seberang terdapat beberapa kelas dari kelas X sampai kelas XII yang berminat dalam olahraga bola basket. tetapi pada sekolah tersebut olahraga yang paling di tonjolkan atau yang sering di ajarkan secara spesifik adalah sepak bola dan voli .

Sejak saya memulai PPL di SMAN 1 Tenggarong Seberang, saya melihat siswa kurang aktif dalam olahraga tidak terkecuali pada saat hari jumat yang biasanya di gunakan untuk melakukan olahraga setelah senam Menurut pngamatan saya, siswa SMAN 1 Tenggarong Seberang banyak kurang dalam hal teknik-teknik dasar dalam bola basket dan tidak tahu sama sekali tentang taktik yang ada di dalam permainan bola basket seperti formasi menyerang dan formasi bertahan. Terkait teknik dasar, siswa SMAN 1 Tenggarong seberang kebanyakan melakukannya dengan asal-asalan tanpa adanya dasar pengetahuan yang di terapkan dalam pelaksanaan teknik dasarnya.

Untuk sarana dan prasarana olahraga bola basket di SMAN 1 tenggarong seberang bisa di bilang cukup lengkap, tetapi lapangan bola basket di SMA tersebut tidak tersedia, jadi untuk lapangan bola basketnya mereka memakai lapangan bola voly yang di setiap ujung lapangan di beri ring sehingga ukuran lapangan tidak sesuai dengan yang aslinya , dan karena olahraga bola basket kurang di ajarkan di sekolah tersebut banyak bola baru yang terdapat di gudang menjadi rusak seperti bola yang masih di dalam plastik baru di kompa pada saat sudah menjadi bentuk bola pada saat bola di usap usap kulit bolanya gampang terkelupas. Saya ingin menganalisis keterampilan bola basket pada siswa karena saat saya berada di sekolah tersebut, cukup banyak siswa yang berminat dalam olahraga bola basket tetapi kurang dalam tekniknya.

\section{B. Rumusan Masalah}

Berdasarkan uraian latar belakang di atas, maka rumusan masalah yang akan diajukan oleh peneliti adalah :

1.Bagaimanakah ketermapilan teknik dasar dribble pada siswa SMAN 1 Tenggarong Seberang?

2.Bagaimanakah ketermapilan teknik dasar Passing pada siswa SMAN 1 Tenggarong Seberang?

3.Bagaimanakah ketermapilan teknik dasar Shooting pada siswa SMAN 1 Tenggarong Seberang ? 


\section{Tujuan Penelitian}

Berdasarkan rumusan masalah yang telah dikemukakan diatas, maka adapun tujuan dari penelitian ini Sebagai Berikut :

1.Untuk mengetahui keterampilan teknik dasar dribble pada siswa SMAN 1 Tenggarong Seberang.

2.Untuk mengetahui keterampilan teknik dasar passing pada siswa SMAN 1 Tenggarong Seberang.

3.Untuk mengetahui keterampilan teknik dasar shooting pada siswa SMAN 1 Tenggarong Seberang.

\section{Manfaat Penelitian}

Hasil Penelitian ini diharapkan dapat memberikan manfaat antara lain sebagai berikut:

1. Sebagai bahan evaluasi bagi sekolah dalam proses belajar, untuk meningkatkan kualiats pembelajaran di sekolah.

2. Untuk mengembangkan ilmu khususnya berkaitan dengan kemampuan teknik dasar bola basket yang telah didapatkan dari bangku perkuliahan.

\section{Kajian Teori}

A. Teknik Dasar Bola Basket

\section{Mengoper dan Menangkap Bola}

Mengoper dan menangkap dalam permainan bola basket adalah satu paket, tidak bisa dipisahkan. Karena dalam bermain basket ada saat mengoper bola dan suatu ketika harus menangkap bola. Jadi keduanya menjadi satu kesatuan.

Mengoper menurut Yolis Y.A. Djami (2018 : 32) adalah memindahkan bola dari seorang pemain kepada pemain yang lain di tempat atau sambil bergerak. Mengoper bola bisa dilakukan dengan satu atau dua tangan dari berbagai posisi. Jenis -jenis operan antara lain:

a. Operan Dua Tangan

1) Chest pass (Operan Dada)

2) Overhead Pass (Operan Atas)

3) Bounce Pass (Operan Bawah)

b. Operan Satu Tangan

1) Baseball Pass (Operan Bisbol)

2) Underhead Pass ( Operan dari Bawah) 
3) Hook Pass (Lemparan samping/mengait)

2. Menangkap Bola

Yolis Y.A. Djami (2018 : 38) menyatakan bahwa menerima atau menangkap bola dalam permainan basket adalah salah satu teknik dasar penting yang harus dikuasai. Karena seringkali kandasnya suatu serangan disebabkan oleh ketidakmampuan atau kegagalan menerima atau menangkap bola operan dengan baik.

3. Dribble (Menggiring Bola)

Dribble atau menggiring menurut Yolis Y.A. Djami (2018 : 40) adalah salah satu cara membawa bola ke segala arah dengan memantulkannya terus-menerus ke lantai menggunakan satutangan secar bergantian bila diperlukan

4. Shooting (Menembak)

Shooting atau menembak menurut Yolis Y.A. Djami (2018 : 45) adalah gerakan mendorong bola ke arah ring/jaring untuk mencetak angka, baik dari posisi diam ataupun sambil bergerak

5. Pivot

Pivot menurut Yolis Y.A. Djami (2018 : 55) adalah gerakan bergerak ke segala arah dengan berporos pada satu kaki. Menurut Nidhom Khoeron (2017 : 50) pivot adalah sebuah teknik memutar tubuh ke segala arah dengan menggunakan salah satu kaki sebagai porosnya

6. Rebound

Herka Maya Jatmika (2017 : 6) menyatakan bahwa Rebound adalah teknik mengagalakn lawan yang ingin memasukan bola ke ring

\section{B. Peralatan dan Perlengkapan Bola Basket}

1. Bola

Ukuran bola yang standar yaitu yang berdiameter antara $749 \mathrm{~mm}$ dan $780 \mathrm{~mm}$ dengan berat antara 567 gram dan 650 gram. Cara mengukur tekanan angina dengan menjatuhkannya dari atas kepala ( $\pm 1,8$ meter) ke lantai atau tempat datar di mana orang yang melakukannya berdiri. Bila bola memantul kembali kira-kira setinggi pinggang $( \pm$ 1,3 meter), artinya tekanan angina atau daya pantulnya baik dan layak untuk dipakai bermain

2. Papan Pantul dan Jaring

Yolis Y.A. Djami (2018 : 18) menyatakan bahwa papan tempat perkenaan bola basket berukuran panjang 1,80 meter dan lebar 1,05 meter. Papan ini bisa berupa kayu 
(papan) setebal $3-5 \mathrm{~cm}$ atau terbuat dari bahan fiberglass (kaca berserat) yang tidak mudah pecah/rusak. Kemudian di beri garis lis (garis bingkai) selebar $5 \mathrm{~cm}$. di tengah papan pantul tersebut harus dibuat kotak dengan ukuran panjang $59 \mathrm{~cm}$ dan lebar 45 $\mathrm{cm}$. letaknya $45 \mathrm{~cm}$ dari garis bingkai atas bagian dalam.

Tinggi papan dari lantai adalah 2,90 meter diukur dari sisi papan paling bawah (paling dekat ke lantai). Atau setinggi 3,05 meter bila diukur dari lantai sampai ke ring (bukan jarring/cincin besi).

3. Lapangan

Ukuran lapangan basket yang standar adalah panjang 28 meter dan lebar 15 meter. Dari ukuran ini, masih boleh ditambah maksimal 2 meter untuk panjangnya dan 1 meter untuk lebarnya.

Di dalam lapangan harus ada tiga lingkaran dengan ukuranyag sama yaitu berdiameter 1,8 meter. Satu berada di tengah-tengah yang dipakai untuk memulai sebuah pertandingan. Dan dua lainnya berada di daerah ring masing-masing yang digunakan untuk jump ball dan/atau free throw (merayah bola dan/atau lemparan bebas atau tembakan hukuman).

\section{Kerangka Berpikir}

Berdasarkan uraian diatas maka penulis menyusun kerangka berpikir sebagai berikut

1. Jika siswa SMAN 1 Tenggarong Seberang memiliki kemampuan dribble yang baik, maka siswa tersebut memiliki keterampilan teknik dasar bola basket yang baik pula

2. Jika siswa SMAN 1 Tenggarong Seberang memiliki kemampuan passing yang baik, maka siswa tersebut memiliki keterampilan teknik dasar bola basket yang baik pula

3. Jika siswa SMAN 1 Tenggarong Seberang memiliki kemampuan shooting yang baik, maka siswa tersebut memiliki keterampilan teknik dasar bola basket yang baik pula

\section{Metode Penelitian}

A. Definisi Konsepsional

1. Dribble merupakan salah satu upaya yang dilakukan oleh pemain bola basket dengan cara menggunakan suatu teknik tertentu yang bertujuan untuk menggiring bola ataupun dapat digunakan untuk melewati lawan pada saat berada di lapangan dan jenis dalam dribble ada dua yaitu dribble tinggi dan dribble rendah.

2. Passing merupakan upaya yang dilakukan oleh pemain bola basket dengan cara menggunakan suatu teknik tertentu yang bertujuan untuk mengoper bola kepada teman 
satu tim. Dalam melakukan passing terdapat 3 teknik dasar yang umum di lakukan yaitu passing dada (Chest Pass), passing atas (Overhead Pass), dan Passing Bawah (Bounce Pass).

3. Shooting merupakan upaya yang dilakukan oleh pemain bola basket dengan cara menggunakan suatu teknik tertentu yang bertujuan untuk memasukan bola kedalam ring dan mendapatkan point dari hasil shooting tersebut. Shoting dapat di bagi menjadi beberapa jenis seperti jump shoot, lay up shoot, hook shoot, Dll.

\section{B. Definisi Operasional}

1. Dribble merupakan teknik yang dilakukan dengan memantulkan bola dengan tangan bertujuan untuk menggiring bola, cara melakukan dribble dengan benar adalah menggunakan ujung jari pada tangan dalam sentuhan bola lalu pantulkan bola untuk melakuka dribble. Ikuti alur pantulan bola pada saat bola sampai di tangan lagi, jangan melawan pantulan bolanya

2. Passing merupakan teknik dasar yang digunakan dalam mengoper bola ke rekan satu tim, terdapat 3 teknik passing yang umum di lakukan yaitu chest pass, overhead pass dan bounce pass.

3. Shooting adalah teknik untuk memasukan bola ke dalam keranjang atau ring, cara melakukan shooting pertama-tama pegang bola di antara dada dan perut lalu angkat bola hingga di depan dahi, tangan membentuk siku-siku dan posisi tangan ada yang di belakang bola dan satunya di samping bola , yang dibelakang bola bertujuan untuk tenaga atau power dalam shooting serta tangan yang di samping bola bertujuan untuk membuat bola seimbang dan untuk mengarahkan bola.

\section{Jenis Penelitian}

Jenis peneitian ini terasuk jenis penelitian deskriptif kuantitatif. Penelitian deskriptif adalah penelitian yang dalam akumulasi datanya tidak perlu mencari atau menerangkan saling berhubungan, menguji hipotesis, membuat ramalan atau mendapatkan makna dan implikasi. Penelitian ini bertujuan membuat pecandraan secara sistematis, faktual, dan akurat mengenai fakta-fakta dan sifat-sifat populasi atau daerah tertentu.

\section{Populasi dan Sampel}

1. Populasi

Populasi adalah totalitas dari semua objek atau individu yang memiliki karakteristik tertentu, jelas, dan lengkap yang akan diteliti. Dengan demikian populasi dalam 
penelitian ini adalah siswa kelas XII IPA 2 dan XII IPA 3 SMAN 1 Tenggarong Seberang.

2. Sampel

Sampel adalah contoh yang dianggap mewakili populasi, atau cermin dari keseluruhan objek yang diteliti. maka untuk itu yang menjadi sampel dalam penelitian ini ialah siswa kelas XII IPA 2 dan XII IPA 3 SMAN 1 Tenggarong Seberang yang berminat dalam olahraga basket berjumlah 20 orang, 12 laki-laki dan 8 perempuan.

\section{E. Teknik Pengambilan Sampel}

Pengambilan sampel dalam penelitian ini menggunakan teknik sampling kebetulan atau sampling seadanya. Menyatakan teknik sampling kebetulan atau sampling seadanya, yaitu bentuk sampling nonprobabilitas dengan cara memilih anggota sampelnya berdasarkan kemudahan mendapatkan data yang diperlukan, atau dilakukan seadanya, seperti mudah ditemui atau dijangkau atau kebetulan ditemukan .

\section{F. Teknik Analisis Data}

Analisis dalam penelitian merupakan bagian penting dalam proses penelitian karena dengan analisis inilah, data yang ada akan tampak manfaatnya, terutama dalam memecahkan masalah peneitian dan mencapai tujuan akhir penelitian. Suatu penelitian dapat digunakan dua jenis analisis, yaitu analisis statistik dan analisis non statistic. Karena data penelitian ini berupa angka maka data ini dianalisis dengan analisis statistik.

Analisis atau pergolongan data merupakna satu langkah penting dalam penelitian. Metode analisis data yang digunakan dalam penelitian ini adalah dengan perhitungan statistik analisis deskriptif dalam pengolahan data penelitian ini menggunakan program SPSS v25

\section{Hasil Penelitian dan Pembahasan}

\section{A. Hasil Penelitian}

Tabel 4.1. Hasil Analisis Deskriptif Tes Keterampilan Teknik Dasar Permainan Bola Basket Putra Pada siswa SMAN 1 Tenggarong Seberang.

Descriptive Statistics

\begin{tabular}{|l|r|r|r|r|r|r|r|}
\hline & N & Range & Minimum & Maximum & Sum & Mean & Std. Deviation \\
\hline Melempar dan Menangkap Bola & 12 & 4 & 19 & 23 & 255 & 21.25 & 1.765 \\
\hline Masukan Bola ke Keranjang & 12 & 7 & 1 & 8 & 51 & 4.25 & 2.050 \\
\hline Menggiring Bola & 12 & 7 & 6 & 13 & 127 & 10.58 & 1.832 \\
\hline
\end{tabular}




\section{Valid N (listwise)}

Sumber : Hasil Perhitungan Data

Dari tabel 4.1 di atas yang merupakan gambaran data keterampilan teknik dasar permainan bola basket pada siswa SMAN 1 Tenggarong Seberang dapat dikemukakan sebagai berikut:

a. Pada tabel melempar dan menangkap Bola diatas siswa SMAN 1 Tenggarong Sebrang, diperoleh total nilai sebesar 255 point dengan nilai rata-rata yang diperoleh 21,25 point, untuk standar deviasi 1,76 point dan data minimal yang didapat 19 point serta data maksimal atau tertinggi 23 point, dengan rentang skor atau selisih 4 point dari 12 sampel siswa.

b. Pada tabel masukan bola ke keranjang di atas siswa SMAN 1 Tenggarong Seberang diperoleh total nilai sebesar 127 point dengan nilai rata-rata yang diperoleh 10,58 point, untuk standar deviasi 2,05 point dan data minimal yang didapat 1 point serta data maksimal atau tertinggi 8 point, dengan rentang skor atau selisih 7 point dari 12 sampel siswa.

c. Pada tabel menggiring bola di atas siswa SMAN 1 Tenggarong Seberang diperoleh total nilai sebesar 51 point dengan nilai rata-rata yang diperoleh 4,25 point, untuk standar deviasi 1,83 point dan data minimal yang didapat 6 point serta data maksimal atau tertinggi 13 point, dengan rentang skor atau selisih 7 point dari 12 sampel siswa.

Tabel 4.2. Hasil Analisis Deskriptif Tes Keterampilan Teknik Dasar Permainan Bola Basket Putri Pada siswa SMAN 1 Tenggarong Seberang.

\section{Descriptive Statistics}

\begin{tabular}{|c|c|c|c|c|c|c|c|c|}
\hline & $\mathrm{N}$ & Range & Minimum & Maximum & Sum & Mean & Std. Deviation & Variance \\
\hline $\begin{array}{l}\text { Melempar dan } \\
\text { Menangkap Bola }\end{array}$ & 8 & 4 & 12 & 16 & 113 & 14.13 & 1.553 & 2.411 \\
\hline $\begin{array}{l}\text { Memasukan Bola } \\
\text { ke Keranjang }\end{array}$ & 8 & 3 & 1 & 4 & 18 & 2.25 & 1.035 & 1.071 \\
\hline Menggiring Bola & 8 & 4 & 6 & 10 & 60 & 7.50 & 1.309 & 1.714 \\
\hline Valid N (listwise) & 8 & & & & & & & \\
\hline
\end{tabular}

Sumber : Hasil Perhitungan Data 
Dari tabel 4.2 di atas yang merupakan gambaran data keterampilan teknik dasar permainan bola basket pada siswa SMAN 1 Tenggarong Seberang dapat dikemukakan sebagai berikut:

a. Pada tabel melempar dan menangkap Bola diatas siswa SMAN 1 Tenggarong Sebrang, diperoleh total nilai sebesar 113 point dengan nilai rata-rata yang diperoleh 14,13 point, untuk standar deviasi 1,55 point dan data minimal yang didapat 12 point serta data maksimal atau tertinggi 16 point, dengan rentang skor atau selisih 4 point dari 8 sampel siswa.

b. Pada tabel masukan bola ke keranjang di atas siswa SMAN 1 Tenggarong Seberang diperoleh total nilai sebesar 18 point dengan nilai rata-rata yang diperoleh 2,25 point, untuk standar deviasi 1,03 point dan data minimal yang didapat 1 point serta data maksimal atau tertinggi 4 point, dengan rentang skor atau selisih 3 point dari 8 sampel siswa.

c. Pada tabel menggiring bola di atas siswa SMAN 1 Tenggarong Seberang diperoleh total nilai sebesar 60 point dengan nilai rata-rata yang diperoleh 7,50 point, untuk standar deviasi 1,30 point dan data minimal yang didapat 6 point serta data maksimal atau tertinggi 10 point, dengan rentang skor atau selisih 4 point dari 8 sampel siswa.

\section{B. Pembahasan}

Hasil pengumpulan dan pengolahan data tes melempar dan menangkap bola putra siswa SMAN 1 Tenggarong Seberang, menunjukan bahwa dari 12 siswa yang mengikuti tes, sebanyak 5 siswa memperoleh kategori "baik", 2 siswa memperoleh kategori "cukup", dan 5 siswa memperoleh kategori "kurang". Maka dapat disimpulkan dari nilai rata-rata yaitu 21,25, melempar dan menangkap bola siswa dalam tes ini termasuk dalam kategori "cukup".

Hasil pengumpulan dan pengolahan data tes melempar dan menangkap bola putri siswa SMAN 1 Tenggarong Seberang, menunjukan bahwa dari 8 siswi yang mengikuti tes, sebanyak terdapat 2 siswi memperoleh kategori "baik", 2 siswi memperoleh kategori "cukup", dan 4 siswi memperoleh kategori "kurang". Maka dapat disimpulkan dari nilai rata-rata yaitu 14,13, melempar dan menangkap bola siswi dalam tes ini termasuk dalam kategori "cukup".

Hasil pengumpulan dan pengolahan data tes memasukan bola ke keranjang putra siswa SMAN 1 Tenggarong Seberang, menunjukan bahwa dari 12 siswa yang mengikuti tes, 
sebanyak 1 siswa memperoleh kategori "sangat baik", 2 siswa memperoleh kategori "baik", 4 siswa memperoleh kategori "cukup", dan 5 siswa memperoleh kategori "kurang". Maka dapat disimpulkan dari nilai rata-rata yaitu 4,25, memasukan bola ke keranjang siswa dalam tes ini termasuk dalam kategori "cukup".

Hasil pengumpulan dan pengolahan data tes memasukan bola ke keranjang putri siswa SMAN 1 Tenggarong Seberang, menunjukan bahwa dari 8 siswi yang mengikuti tes, sebanyak terdapat 3 siswi memperoleh kategori "baik", 3 siswi memperoleh kategori "cukup", dan 2 siswi memperoleh kategori "kurang". Maka dapat disimpulkan dari nilai rata-rata yaitu 2,25, memasukan bola ke keranjang siswi dalam tes ini termasuk dalam kategori

Hasil pengumpulan dan pengolahan data tes menggiring bola putra siswa SMAN 1 Tenggarong Seberang, menunjukan bahwa dari 12 siswa yang mengikuti tes, sebanyak 3 siswa memperoleh kategori "baik", 8 siswa memperoleh kategori "cukup", dan 1 siswa memperoleh kategori "sangat kurang". Maka dapat disimpulkan dari nilai rata-rata yaitu 10,58, menggiring bola siswa dalam tes ini termasuk dalam kategori "cukup".

Hasil pengumpulan dan pengolahan data tes menggiring bola putri siswa SMAN 1 Tenggarong Seberang, menunjukan bahwa dari 8 siswi yang mengikuti tes, sebanyak terdapat 1 siswi memperoleh kategori "sangat baik", 5 siswi memperoleh kategori "cukup", dan 2 siswi memperoleh kategori "kurang". Maka dapat disimpulkan dari nilai rata-rata yaitu 7,50, menggiring bola siswi dalam tes ini termasuk dalam kategori "cukup".

Secara keseluruhan hasil penelitian teknik dasar permainan bola basket pada siswa SMAN 1 Tenggarong Sebrang menunjukan bahwa dari 12 siswa yang mengikuti tes, terdapat 4 siswa yang memperoleh kategori "baik", 5 siswa yang memperoleh kategori "cukup", 2 siswa yang memperoleh kategori "kurang", dan 1 siswa yang memperoleh kategori "sangat kurang". Maka dapat di simpulakn dari nilai rata-rata yaitu 149,99, bahwa tingkat keterampilan teknik dasar permainan bola basket siswa yang minat dalam olahraga basket di SMAN 1 Tenggarong Seberang masuk dalam kategori "cukup".

Secara keseluruhan hasil penelitian teknik dasar permainan bola basket pada siswi SMAN 1 Tenggarong Seberang menunjukan bahwa dari 8 siswi yang mengikuti tes, terdapat 1 siswi yang memperoleh kategori "sangat baik", 5 siswi yang memperoleh kategori "cukup", dan 2 siswi yang memperoleh kategori "kurang". Maka dapat di simpulakn dari nilai rata-rata yaitu 149,84, bahwa tingkat keterampilan teknik dasar permainan bola basket siswi yang minat dalam olahraga basket di SMAN 1 Tenggarong 
Seberang masuk dalam kategori "cukup". Hasil tersebut menunjukan keterampilan yang dimiliki sisa dan siswi berbeda-beda dan masih banyak siswa maupun siswi yang kurang terlatih dalam penguasaan teknik-teknik dasar olahraga bola basket.

Merujuk dari pembahasan dapat dijelaskan bahwa tingkat keterampilan siswa dan siswi yang berminat dalam olahraga bola basket di SMAN 1 Tenggarong Seberang masuk dalam kategori "cukup". Hal ini dipengaruhi oleh beberapa faktor diantaranya yaitu tidak tersedianya lapangan utuk bermain bola basket, tidak adanya sarana untuk menyalurkan hoby dalam olahraga bola basket di sekolah seperti ekstrakurukuler utuk bola basket.

Keterampilan permainan bola basket siswa dan siswi SMAN 1 Tenggarong Seberang masuk dalam kategori "cukup", sehingga menjadi tugas guru PJOK untuk meningkatkan keterampilan dasar bola basket siswa. Sebab teknik-teknik dasar dalam tes ini menjadi modal utama dalam permainan bola basket, karena teknik-teknik ini adalah teknik yang paling dasar sebelum masuk ke teknik-teknik selanjutnya.

\section{Kesimpulan dan Saran}

\section{A. Kesimpulan}

Setelah dilakukan analisis data mengenai keterampilan teknik dasar bola basket pada siswa dan siswi SMAN 1 Tenggarong Seberang, maka dapat diambil beberapa kesimpulan bahwa:

1. Keterampilan melempar dan menangkap

Berdasarkan analisis data dan pembahasan yang telah dikaji sebelumnya maka dapat disimpulkan bahwa keterampilan melempar dan menangkap pada siswa dan siswi SMAN1 Tenggarong Seberang sama-sama termasuk dalam kategori cukup.

2. Keterampilan memasukan bola ke keranjang

Berdasarkan analisis data dan pembahasan yang telah dikaji sebelumnya maka dapat disimpulkan bahwa keterampilan memasukan bola ke keranjang pada siswa dan siswi SMAN 1 Tenggarong Seberang sama-sama termasuk dalam kategori cukup.

3. Keterampilan menggiring bola

Berdasarkan analisis data dan pembahasan yang telah dikaji sebelumnya maka dapat disimpulkan bahwa keterampilan menggiring bola pada siswa dan siswi SMAN 1 Tenggarong Seberang sama-sama termasuk dalam kategori cukup.

\section{B. Saran}

Berdasarkan hasil analisis data dan kesimpulan yang telah tersaji diatas, maka dapat dikemukakan saran-saran sebagai berikut: 
1. Kepada pihak sekolah

Hendaknya sekolah membuat ektrakurikuler bola basket untuk mendukung siswa yang berminat dalam olahraga bola basket, sebab di SMAN 1 Tenggarong Seberang peminat untuk olahraga bola basket lumayan tinggi, tetapi tidak ada sarana untuk menyalurkannya. Dan untuk sarana olahraga bola basket agar dapat di buat seperti lapagan khusus untuk olahraga bola basket jadi siswa bisa berlatih meskipun tidak ada ekstrakurukuler bola basket di sekolah, karena untuk di separi lapangan basket tidak ada.

2. Kepada siswa yang berminat olahraga bola basket

Untuk siswa dan siswi yang berminat dalam olahraga bola basket agar lebih melatih teknik-teknik dasar olahraga bola basket karena jika kalian memiliki teknik yang baik maka permainan kalian akan terlihat baik juga, sehingga dalam pelaksanaan tidak terasa kaku.

\section{DAFTAR PUSTAKA}

Diana, Marta. 2008, Bola Basket Konsep \& Teknik Bermain Bola Basket. Ciputat: Cerdas Jaya

Djami, Yolis Y.A. 2018, Basket Untuk Pemula Teori \& Praktek. Yogyakarta: CV. Budi Utama

Faturrahman, Dkk. 2012, Pengantar Pendidikan. Jakarta: PT. Prestasi Pustakarya

Husadarta, H.J.S. 2010, Sejarah dan Filsafat Olahraga. Bandung: Alfabeta

Jatmika Herka Maya. 2018, Permainan Bola Basket Teori dan Praktek. $\quad$ Yogyakarta: UNY press

Kementrian Pendidikan dan Kebudayaan Republik Indonesia. 2014, Pendidikan Jasmani dan Kesehatan Kelas X. Jakarta: Kementrian Pendidikan dan Kebudayaan

Khoeron Nidhom.2017, Buku Pintar Basket. Jakarta: Anugrah

Mahmmud,H. 2011, Metodologi Penelitian Pendidikan. Bandung: Pustaka Setia

Nurhasan. 2001, Tes dan Pengukuran Dalam Pendidikan Jasmani. Jakarta:

Direktorat Jendral Olahraga

Rahayu, Ega Trisna. 2013, Strategi Pembelajaran Pendidikan Jasmani. Bandung: Alfabeta

Rosdiani, Dini. 2013, Perencanaan Pembelajaran Dalam Pendidikan Jasmani Dan Kesehatan. Bandung: Alfabeta.

Sutanto, Teguh. 2016, Buku Pintar Olahraga. Yogyakarta: Pustaka Baru Press 
